\title{
Maybe That's Enough: Towards the Social, and Socially Conscious, Micro-Budget Filmmaker
}

\author{
Brandon Niezgoda
}

\section{Introduction}

In an age of conglomeration, tentpole films, Indiewood Cinema-in an age of... Ultron-Michael Z. Newman sees a multitude of individuals searching for an authentic, autonomous, alternative cinema.

He writes of this seemingly intangible cinema as

"Authentic, insofar as a film is recognized to be the sincere production of an artist or group of artists. Autonomous, to the extent that the artist or group of artists is free to pursue their personal agenda and not constrained by business demands. And alternative, as the authenticity and autonomy of the film and its production is regarded as a contrast to the dominant process for making movies, which is the Hollywood studio way (2009, p.222).

Authors, academics, and patrons-whether they know it or not-pine for this form of cinema. Whereas each of these trends goes against the Hollywood grain, "each can be viewed as an implicit (or explicit) assault on the conventions of the studio film, the mainstream movie, and the institutions through which it is experienced—or at least as an effort to provide a needed counterbalance and response to it (2009, p.222). Amidst endless simulacra, in April 2014 a small passing article was posted on the blog for streaming website Fandor. The article was to commemorate the digital distribution of Joe Swanberg's All the Light in the Sky (2011), and poses some sort of answer or hope that this type of cinema is not out of reach.

For the occasion Fandor hosted a conversation between Swanberg and fellow director Frank V. Ross. Interpreting their dialogue, Kevin Lee appreciated something atypical. Instead of allowing the medium to dictate the representative format of a publicity interview, Swanberg chose to speak of Ross's work. The two share a collaborative friendship. Ross has acted and helped with Swanberg's films. Swanberg has assisted in Ross's films. This was not a one sided discussion. The two share a mutual appreciation, and it becomes increasingly clear while watching that neither would be in their position, although this by no means indicates any type of excessive wealth or spotlight, without the other.

Lee believes that this is "the kind of rapport that might be the saving grace of low-budget independent filmmaking as it faces its latest set of crises." The directors prove to be very sober about their practice. "We shouldn't expect to make any money from our movies," Joe reflects. Lee concludes his piece with this statement; "They seem sincerely grateful that their films exist, thanks in a large part to collaborative goodwill and mutual support. Maybe all we have is each other. And maybe that's enough." The goal of this paper is to see what role social capital has for Joe Swanberg and his contemporaries, in opening up new modes of authentic, autonomous and alternative cinema. "I sense a disconnect between, within Mumblecore in general, the sort of like antagonisms towards this idea of Mumblecore like these films weren't meant to have hype around them. They're not able to stand up to that sort of expectation," Joe Swanberg recounts in a 2011 interview. This paper asks what types of expectation are they supposed to be judged by and what the curious results specify. 


\section{Literature Review}

With his first two films Swanberg's work became engulfed under the notorious Mumblecore umbrella; part genre, part movement, part moment. Sound mixer Eric Masunaga jokingly devised the moniker to describe films he had worked on that were screening at 2005's South by Southwest Festival. It went viral when filmmaker Andrew Bujalski used it in an Indiewire.com interview soon after.

It is tough to believe, now or ever, that there is any room for autonomous cinema. When film critics encountered the works of the Mumblecore directors, many quickly denounced the films as being insignificant, and sanitized. Devin Faraci deemed Mumblecore as "the blandest, most self-indulgent bullshit, aimed only at the narcissists who make it” (personal communication, Sept. 22 2012).

Stuart Cunningham writes in, "Rates of Change: Online Distribution as Disruptive Technology in the Film Industry," that "much debate in media and communication studies is based on exaggerated opposition between the digital sublime and the digital abject: overly enthusiastic optimism versus determined pessimism over the potential of new technologies" (2010, p. 119). Yet, reviewing contemporary literature on technological determinism and filmmaking proves that the simple fact for having cameras cannot account for Joe Swanberg's continuance in the industry.

Similarly, there are academics who focus on mythologies of individualism, film students who dream of being found at Sundance, and audiences who see Indiewood as providing some sort of (illusion of) choice.

This literature review works to deconstruct mythologies of technological determinism, and autuerism. Ultimately, the amount of agency afforded to other forces in their role in for promoting success for a film director, is less agency that can be given to social capital.

\section{Technological Determinism}

The term 'technological determinism' was apparently coined by the American sociologist and economist Thorstein Veblen (1857-1929). Just like other deterministic theories, technological determinism seeks to explain social and historical phenomena in terms of one principal or determining factor. It is a doctrine of historical or causal primacy. In its most extreme form, the entire form of society is seen as being determined by technology: new technologies transform society at every level, including institutions, social interaction and individuals. At the least a wide range of social and cultural phenomena are seen as shaped by technology. "Human factors" and social arrangements are seen as secondary.

Various non-Marxist theorists such as Sigfried Giedion, Leslie White, Lynn White Jr, Harold Innis and Marshall McLuhan have adopted the stance of technological determinism (Chandler, 1995). McLuhan's basic premise is that all technologies are extensions of human capacities. Tools and implements are extensions of manual skills; the computer is an extension of the brain. It was up to his followers- Neil Postman, Walter Ong, and Joshua Meyrowitz,to revisit and make sense of his paradoxical oeuvre, as well as to infer a "general media theory" (sometimes referred to as "medium theory") from his pun-filled prose (Laron, 2003, p. 2).

Despite criticisms and misreadings, technological determinism persists in manifold theoretical and abstract accounts of the relationship between the technical and the social. It remains in the justifications of actors who are keen to promote a particular direction of change, and as part of a broader public discourse which seeks to render technology opaque and beyond political intervention and control (Wyatt, 2008, p. 167).

Several authors, have written about the age of media convergence to "make sense of the ways in which new cinema technologies are being used not only by the major media corporations but also by DIY independent filmmakers" (Tryon, 2007, p.4). Emphasizing technological determinism above all else has been found provincial. John Belton claims the digital revolution is a "false revolution." Cheaper technology has certainly helped cinema become a more productive and democratized medium. But this is only part of it; a soft determinism. In their critical report on the contemporary film industry Eliashberg, Elberse and Leenders state "the benefits of digital technology will change the production process but not lead to fundamental shifts in power structures, (2006, p. 645). Robert Sickels confirms that belief in his book American Film in the Digital Age. "The movie industry movies into the digital age, it's undergoing cataclysmic industrial changes", he writes, "but when the dust settles for a while, neither its more than a century old-basic premise, providing for-profit entertainment to consumers, nor the underlying 
structure required to control the market—production, distribution, and exhibition-will have changed" (2011, p. 163). Sickels only sees how things are produced, distributed and exhibited as changed. The major media companies will still control them.

When writing “On Digital Media as a Potential Alternative Cinema Apparatus: A Marketplace Analysis," (2004) Robert Irwin believes that it is not simply a high-quality, low cost digital revolution that will come and save us but rather what is necessary is having "enough people must have the requisite knowledge of film and video production, digital marketing, and business models," coupled with the "relatively modest capital needed to establish operations" (15). Capital needed for creating a film is secondary. Still, no-budget and micro-budget cinema has been significantly overlooked for political reasons. David Bordwell finds that being empirical does not rule out being theoretical. He has made a powerful case for what he calls middle-level research (Shand, 2008, p. 2). Those working outside of the Hollywood industry have been ignored by the public, and researchers.

But the struggles of these renegades to produce work and to have it seen underscore how deeply amateur/professional divides had been ingrained into social and economic practice. In short, make amateur technology smaller; make film stocks reversal, so that prints can't easily be struck; monopolize and deny access to distribution; offer no viable editing or sound capabilities... and amateur media production is rendered private, frivolous, and inconsequential (Fox, 2004, p.8).

Fox points towards future research because "what the non-Lucases of the world do with their potential digital power remains to be seen" (15). Joe Swanberg made his second feature, LOL, in 2006. The film examines relationships of three men in their twenties. Art reflects life here. He himself graduated from Southern Illinois University Carbondale, where he developed in interest in emerging video technology and the creative possibilities of the internet. He became an avid web designer in school. While his second film LOL focuses on the sometimes troubling and inept interpersonal tendencies engendered by digital technology, the filmmaker doesn't see himself as singularly interested with technology. The director became disinterested with "tech-heads," and with the repeated Q\&A questions about how the film was made, and with what equipment. For Joe Swanberg, and his collaborators for the film C. Mason Wells and Kevin Bewersdorf, they simply worked and cared about the camera they had; and at that point it is simply the only camera they could afford.

\section{Auteurism}

Swanberg, and a few contemporaries, have also been deemed as prolific and singular successes. They are outliers who have caught fire and never went away; who are good enough to be drawn up to the majors like Quintin Tarantino, from working at blockbuster. This all points towards the theory of auteurism which is a similarly stubborn mythology of contemporary cinema. Auteur theory stems from the work of Cashiers Du Cinema. Advocated by director and critic Francois Truffaut in his 1954 essay "A Certain Tendency of French Cinema," and subsequently defined with the help of several other critics, especially Godard, Eric Rohmer, and Jacques Rivette auteur theory states that some directors (based on subjective judgments of value), are auteurs who possess a personal signature. This leaves scriptwriting to a secondary level, simply supplying the raw material (Marie, 2003, p. 41).

From its induction, the theory has been protested for its provocative and paradoxical nature. It ultimately betrays and denies the collective nature of the whole cinematic creation process, causing theorists to constantly deconstruct its meaning and implications. In his iconic essay "Notes on Auteur Theory," Andrew Sarris regards auteur theory as a nascent idea, having no definition in the British and English language. Francois Truffaut himself admitted that it was merely a polemical weapon for a given time and a given place; one situated within a classical French cinema of book adaptation.

Janet Staiger focuses on the historical account of auteurism. By the mid-1950, and in the post-World War II era, limited output, independent production, and the package-unit system typified Hollywood. With the end of the studio era, the package-unit system further intensified the need to differentiate the product on the basis of its innovations, its story, and its stars. The success of auteur films in the 1970's and 1980's within the package system did not give directors, actors, or production staff more funding; but instead made them increasingly dependent on studio financing to produce and distribute such big films. The package unit system made the blockbuster the center of the industry (1985, p. 368).Highly profitable films then were used for growth purposes, diversifying into areas which might provide a stable growth in come to counterbalance more speculative film-finance operations. Rather than 
seeing an industry mature, directors like Francis Ford Coppola admire the Hollywood model of the 1930's; voicing hope that film production might attain the infectious team spirit of the theatrical rehearsal room (Lewis, 1998, p.58). While it offers a more manageable way for critics to debate films, it misinterprets the actual models of production. Auteurism is one of many myths perpetuated in the film industry.

"A critical project that aimed to venerate those directors that somehow managed to repeatedly produce films that were distinguishable from the standard commercial entertainment has ended up as a theoretical project that questioned the very capacities of authorship through both ideology's capacity to determine the social subject and the instability of language and representation," (Sellors, 2011, p.4).

This shift allows us to refocus our attention from the coherent picture of a film's reception to the more complicated situation of its production; the political economy of a film. A more mature use of the theory has seen auteurism as within a "nexus of communicative alliances" that permit share positions built on patterns of simultaneous innovation, recognition, and repetition. This is seminally important in understanding film authorship, as it promotes a historically robust understanding of the actual means which a film comes about; a more accountable analysis of how films are meaningful and culturally significant. For instance, Federico Pacchioni’s Collaborative analysis on Fellini and his screenwriters is able to "provide an assessment of lesser-known influential writers, identifying the authorial and cultural network behind the films and giving a concrete representation of the evolution of Fellini's approach to filmmaking" (2010, p. p. IV). For those auteurs such as Dominique Cabrera, Noemie Lvoksky, Laetitia Masson, Mario Vernoux written about by Hamid Naficy in his book An Accented Cinema, their personal work should never been seen removed from social intimacy; it should be seen as a continuing possibility of constructing new solidarities through the intimate.

For Jean Luc-Godard, the auteurist style eventually did not sustain what morally his goal as a director was. His turn post 1968 to the Dziga Vertov group shows that collaboration is the core, crux, and sometimes burden of filmmaking as Truffaut and Godard's friendship never survived past a rift in 1973 over the aesthetics of cinema. As auteurist cinema fell into some of the same commodity driven functions that the Hollywood package system distributed, working collectively highlighted different emphases. By working collectively and withholding his personal "signature" (the art consumer's guarantee of “originality") Godard challenges this glorification of the individual, and by de-emphasizing the exchange value of his reputation, Godard attempts to shift the film-goer's attention to the use value of a film." Authors like Rosanna Maule look "Beyond Auteurism" reconfiguring the sociocultural function of the film author and advocating for a historicized view of the category with regards to modes of film production and reception" (14).

Swanberg started making movies with his Dad's camcorder, with brothers and friends acting in them. Later in high school his parents signed him up for film class at college in Chicago, shooting on 16mm. At Southern Illinois Carbondale he met his future wife Kris Williams. Kissing on the Mouth was something he had in the works for a while. Kris and Swanberg got serious about the film around Christmas 2003, when the script writing began. Kate Winterich then agreed to be in the movie. First shooting began in late February 2004, and high school friend Kevin Pittman joined not long after. The four individuals were the entire cast and crew. A lot of this first film was improvisation. With all full time jobs, the film was made shooting at night or on the weekends. LOL was similarly shot by friends. Kevin Bewersdorf composed the soundtrack while in Berlin, spending nights packed into a friend's small apartment for internet and communicating with Swanberg. The budget for the picture was only $\$ 3,000$.

In an iconic event, Joe Swanberg and critic Devin Faraci held a spirited debate in a boxing ring at the 2012 Fantastic Fest. Faraci attacked Swanberg's films as being insignificant, and opportunist.

Faraci: “...Mumblecore is the opposite of everything that's great about indie film. It's the laziest form of filmmaking. It's a bunch of middle class and upper class white kids whining about their ennui and their middle class white lives in front of a camera, without a script, without good actors. Here's what you need to make a Mumblecore movie: a sense of entitlement, white skin, and Greta Gerwig, and that's it...” (qtd. in Singer, 2011).

Devin Farci's interpretation ignores the specific social and political circumstances of Swanberg's work. His films are made by friends - many with no hope or expectation that it would be viewed by anyone else but friends and acquaintances; and some, so delicate that they actually strained relationships. 


\section{Social Network Analysis}

Social Network Analysis is a body of work, and methodology, directly suitable to address issues of organizational communication that this study focuses on. SNA has been used to describe and measure modes of partnership, alliance and association to have a geopolitical understanding that many disciplines cannot offer.

Network Analysis allows researchers to examine, on a small scale, an individual's circle of contacts and how those contacts serve them. The foundations are both motivational and cognitive. Researchers explain the urge to "network" and the limitations of human abilities to manage networks. Two kinds of basic human motivations respond to primary needs; 1) to feel safe and 2) to reach out (Kadushin, 2011, p. 56). These correspond to two basic and complementary aspects of social networks: the connections between some of the elements of a network and the holes or non-connections between other elements. One motivation is to stay within one's social cocoon, for the connections between people and social units lead to feelings of safety, comfort, and support. Another motivation is to reach out and make connections where there were none. In addition to these primary motivations, there is one created by the network itself. It goes by various names such as envy, "status seeking," or "keeping up with the Joneses." Networks are not only about getting things done but about "community", "social circles", and the "social support" one receives from these communities, (Kadushin, 2011, p. 56).

Social Network Analysis also works on a larger scale, to see how organizations and societies adapt and function. There are several seminal studies essential to the discussion of social capital and film collectivity. Robert Putnam's seminal book Bowling Alone (2001), is formative research featuring multiple regression analysis correlating high social capital with relative levels of success. Fowler and Christakis have recently confirmed these ideas, finding that happiness tends to be correlated in social networks (2008).

Felton and Graham (2010) have found similar benefits in outer suburban Australia. Gall (2010) sees the alternative filmmaking practice of Punk Cinema as being paramount to their success "exploring notions of a socialized practice centered upon participation, non-hierarchal structures and the development of radical filmmaking strategies outside of traditional models (2)." Elizabeth Furling in his 2010 study of a Portland Oregon artistic collective has found substantial benefits of cooperation and place. Coe has seen interpersonal relationships as a key element in the generation of an indigenous Vancouver filmmaking industry (2000) and Kean Fan Lim has found Hong Kong filmmaker's ability to new cross-scalar production networks and target new markets as to remain competitive (2006).

In his 2014 article, "The Collaborative Advantage," Yosh Beier writes "collaborative capacity-the ability to collaborate and co-create has become the new competitive frontier for organizations.” Mark Lorenzen and Florian Taube's 2008 research conclude that the existence of a well-defined and geographically centered social network among producers, directors and other key roles in filmmaking in Mumbai influences the evolution of an upstart "Bollywood model" of filmmaking remarkably different, and experiencing recent surges of performance and export.

Lilach Nachum found the competitive advantages that firms in clusters develop when analyzing the external linkages of firms in the media cluster of Central London. Stefan Kratke draws from Bruno Latour's Actor Network Theory to find that major innovation impulses arise from the interlinking of knowledge resources. Dean Simonton's article "Group Artistic Creativity" works against the image of the "lone genius" that pervades both the mass media and research literature to research the productivity found in group artistic creativity in clusters. Rob Sabal, as a theorist and professor recounts that it is essential for the film production teacher to foster a collaborative environment. Knowing fully that the romantic notion of the artistic standing outside of society is both a fiction and an impediment to quality artistic production, Sabal sees this as an essential task.

The industrial movie industry is filled with conglomerate ties; its own form of networked affiliations from actors and director companionships. Steven Peacock evaluates the positive influence in the continued collaboration of Greengrass and Damon in his 2012 article. Pixar's network culture is praised by Catmull (2008), claiming success as a direct result of their open communication channels, and rich pre-production and post-production network ties. Gino Cattani and Simone Ferriani advance a relational perspective in studying creativity in Hollywood, recognizing a core/periphery perspective driving cinematic achievements in Hollywood (2008). To find success in Hollywood, there has always been an emphasis on "who you know." So too, must this emphasis be magnified for micro-budget industries. Mark Deuze's 2007 article "Convergence Culture in the Creative Industries" acknowledges that the key to understanding the new media ecosystem as "based on networked technologies that are P2P in organization and collaborative in principle” (257). 


\section{Methodology}

This study focuses on the activated, deactivated, and reactivated modalities of social capital of Joe Swanberg and contemporary filmmakers. The Internet Movie Database (IMDb), has a tremendous amount of data on virtually every movie ever made. The electronic source was used in this study to collect ego-network data.

The sample for this study are alters (actors, producers, etc.) from Joe Swanberg's 12 feature films. Feature films are identified as over fifty minutes in length. Anthology films, such as Autoerotic with directed segments from Joe Swanberg and Adam Wingard, are not included. Members are color coded, indicating chronologically their first collaboration in one of Swanberg's feature films. White- Kissing on the Mouth (2005), Orange-LOL (2006), YellowHannah Takes the Stairs (2007), Forest Green-Nights and Weekends (2008), Cyan-Alexander the Last (2009), BlueCaitlin Plays Herself (2009), Slate Blue-Uncle Kent (2011), Red-Silver Bullets(2011), Art History(2011)- No New Collective Members, Pink- The Zone(2011), Lime Green- Marriage Material (2012), Lavender- All The Light in the Sky (2012). Using IMDB's “Who's worked with who" function, in a one-mode network, each collaborator is then compared to every other, creating a weighted value. A one-mode Agency matrix was then created, and subsequently imported to UCINET. Sociogram for visual analysis is used through NodeXL.

\section{Results}

Including all crew members, cast members, set workers, Joe Swanberg had a total of 118 alters in his feature film ego-network. This is an incredibly small list, recognizing that Blockbuster films employ hundreds of works in one film. While seemingly small, the sociogram reveals a staggering amount of data to be extrapolated.

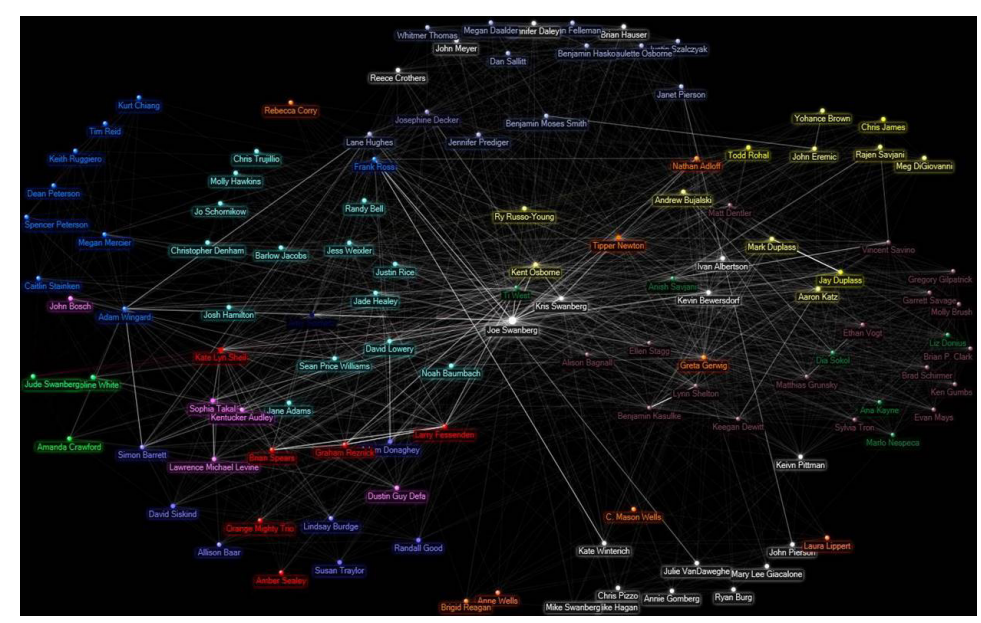

Figure 1. Joe Swanberg Feature Film Ego Network

The network encompassed an astounding 3,774 unique edges, and an average geodesic distance of 1.712008; with the maximum possible being 2 as each member is connected to Joe Swanberg. With Joe Swanberg removed from the network, the average Geodesic Average is 1.779531 with a Maximum Geodesic Distance of only 3. Of essential importance for Joe Swanberg's ego network are the edge weights; shown on the graph by opacity levels. Brothers Mark and Jay Duplass, who recently wrote, directed, and produced HBO's Togetherness have 35 collaborations together. Second is Joe Swanberg and his wife Kris Swanberg who have collaborated 24 times, and third are Brian Spears and Larry Fessenden with 19 collaborations. Calculated through the program Gephi, the average node degree is 31.983, with the average weighted degree at 52.542. Joe Swanberg has a degree of 177 (of course collaborating with every person in his own network), but a weighted degree of 391. Fifteen people in the network have weighted densities of more than 100. However, this is not to say that every person in the network has a high density. There are those, particularly from Swanberg's earlier films, who were only present in the beginning. By Swanberg's 2011 
films he had united with a core group of directors including Frank V. Ross, Adam Wingard, and Ti West. Adam Wingard iconically dropped out of Fox's “The Lot," not willing to perform for studio heads. Although they are more horror film based, Swanberg had been asked to act in his friend's films. The contingent of West, Wingard and his writing partner Simon Barrett make up what is called "Mumblegore." This partnership and merging of horror and communicative based cinema has been mutually beneficial for both parties.

Important is the high density of members within Joe Swanberg's films. He collaborated with couple Lawrence Michael Levine and Sophia Takal in his film The Zone. Swanberg's candid directorial techniques featuring sex, and intimacy, could only be done with people who trust each other. Takal recounts the experience in a 2012 Hollywood Chicago interview.

I'm in Ti West's [segment]. It was the best thing ever. It was just me, Joe, Ti and Kate sharing a hotel room in Arizona, going out for karaoke every night, shooting sometimes and seeing the Grand Canyon for the first time. It was my birthday weekend and they were really nice to me. I didn't even know that they were submitting it [to] festivals. I had no idea what was going to happen with it, and the fact that it's this buzzy horror movie is really funny to me. It was such a fun, mellow time.

Kent Osborne's central position in the network is extremely important; working as a broker in many relationships; especially when regarding Osborne's already solidified position in the industry as a primary developer of Sponge Bob $\underline{\text { Square Pants. Swanberg collaborated with other members outside of the film industry. His film Caitlin Plays Herself }}$ features primarily peripheral members from the art world.

For Joe Swanberg to have such a big weighted density in his ego-network means that he is doing much more than acting. Rather, he must be playing various roles in other people's networks besides directing. He must be in the core and periphery other people's ego networks.

Frank V. Ross, who Swanberg has developed a friendship with, has at this point directed seven feature films; Oh! My Dear Desire, Queitly on By, Hohokam, Present Company, Audrey the Trainwreck, Tiger Tail in Blue, Bloomin Mud Shuffle.

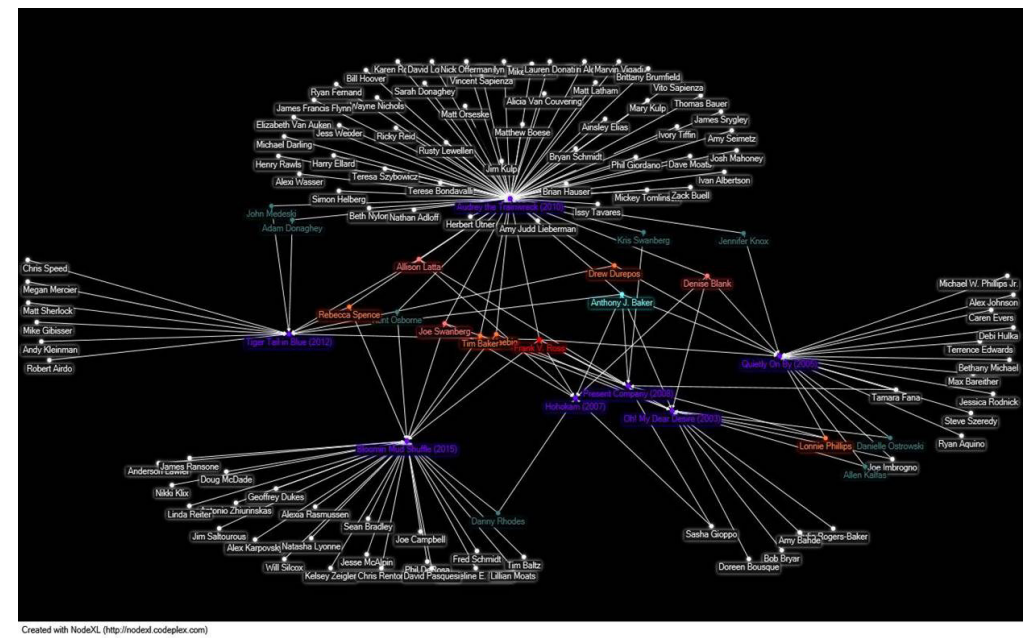

Figure 2. Frank V. Ross Ego Network

Represented above is a two mode, undirected, unweighted ego network of Frank V. Ross's feature films. Members are color coded. Those with only one collaboration are white, two films are green, three films are orange, four films are peach, five films are yellow, and six films are cyan.

Joe Swanberg has appeared in four of Frank V. Ross's films. What is clear about Frank V. Ross's network is that he has various people in the center of the network that are constantly repeated in his films. Interestingly, some of these core members do not repeat in Swanberg's. Anthony J. Baker has appeared in 6 out of 7 of Frank V. Ross's films, playing key and pivotal acting roles in them. He has only acted in one other thing besides this. This idea brings to light that there are those members in people's network that are devoted to only their friend's filmmaking. Denise Blank has appeared in four of Frank V. Ross's films, with no other credits. Along with the devoted friends, Joe 
Swanberg provided publicity for Frank V. Ross's film Tiger Tail in Blue when providing his top 10 films of the year list.

Joe Swanberg similarly plays peripheral roles in other people's ego-networks. Zach Clark has made four feature films in his career. Rock and Roll Eulogy, Modern Love is Automatic, Vacation!, and White Reindeer.

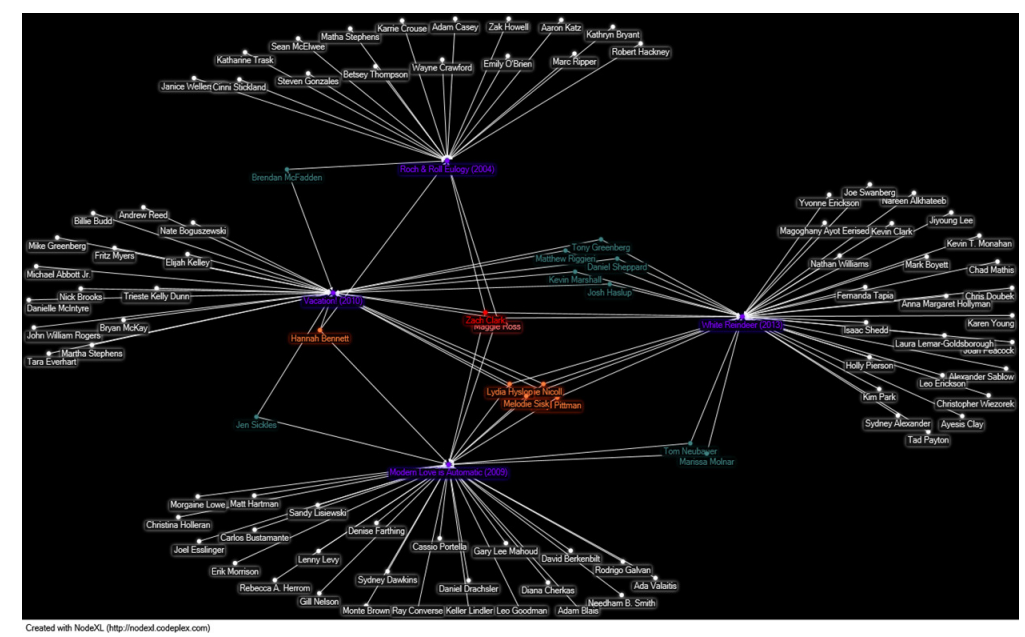

Figure 3. Zach Clark Ego Network

Presented is a two mode, unweighted, undirected network for Zach Clark's feature films. Purple nodes reflect the four films directed. Nodes are color coded. Nodes with only one collaboration are on the peripheral, in white Members with two collaborations are green. Members with three collaborations are orange, and members with four collaborations are Peach. Zack Clark is red. Joe Swanberg only appears in one of the films, acting in White Reindeer. Clark, as with Frank V. Ross, has a core group of members including Maggie Ross, and Hannah Bennet. Maggie Ross has twelve acting credits, with her last five being outside of Zach Clark's work showing that Zack Clark's films worked as a jumping off point for her to enter the industry. Hannah Bennet's only three acting credits are working for Zack Clark, showing that she is devoted to helping and collaborating with Clark.

Joe Swanberg similarly appears in only one of Andrew Balas's films. Andrew Balas is a micro budget director. With his wife he has founded Robel Films. Balas and his wife Deidre Helrey met in college. They were continuously paired together in acting courses because they were both tall. They recently recounted this story in their part documentary Ice Saints: detailing the lead up, and implications of their wedding together.

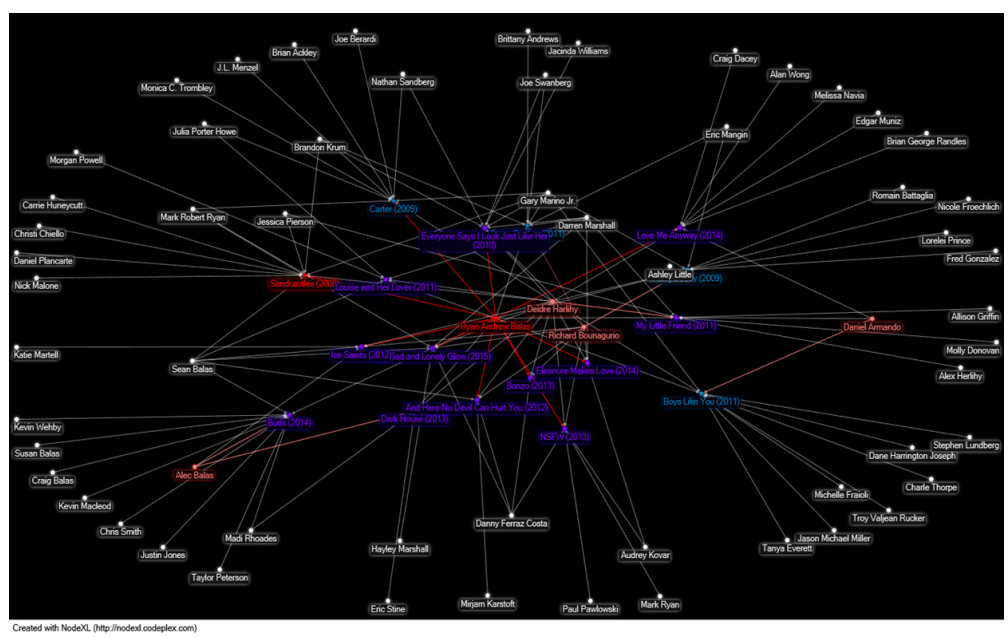

Figure 4. Directed Robel Films Network 
Shown above is a two mode, directed network of all of the Robel films. Important to note, is that members in these two early films before the creation of the production company, helped comprise cast and crews for Robel. These other films include Sandcastles (2008), and Carter (2009).

The red lines show who directed the films. Robel Films is not solely the directorial work of Ryan Balas. Rather,

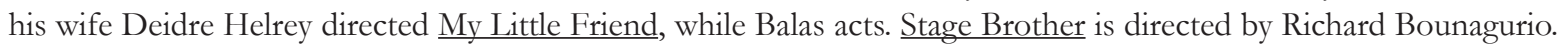
Joe Swanberg directed a small super 8 segment for the film that followed Bounagurio's sister as she struggles with the decision to become a porn actress. Core members of the group include Balas's family members, who has similarly directed films for the collective while Ryan Balas plays supportive roles.

Truly, at the core of the network, is Balas and Helrey. The continued collaboration with each other, and the focus at the wedding as much about the two keep on making art, as love, is touching. Similarly, is Kris Swanberg's position in Joe Swanberg's ego network. Kris Swanberg continuously plays significant roles in Swanberg's films, and he in hers. Kris Swanberg now has directed two feature films, It was Nice But I'm Ready to Come Home, and the aptly named Empire Builder. Swanberg coproduced the film with his wife. Kris Swanberg used the same music group, the independent Orange Mighty Trio that Swanberg used for his Silver Bullets and All the Light in the Sky. He has created a mutually beneficial relationship with the group; directing a music video for them. For Empire Builder, Joe Swanberg starred in the picture with Kate Lyn Sheil about a new mother who strays away from her distant husband and has an affair. Joe Swanberg and Kris Swanberg's child, Jude Swanberg appears in the film. He was appeared in Joe Swanberg's Marriage Material, and Art History.

Starting with friends and family, by 2011 through connections engendered Swanberg had created a self-sustaining network in linking with similar filmmakers who similarly relied on the good will and mutual support of others to get to this point in their career. At the end of Art History, a movie made in Joe Swanberg's four feature films in 2011, the film cuts back to Joe Swanberg and Kris Swanberg taking care of Jude. The two have a candid discussion about Swanberg's filmmaking; as he continues to seemingly make the same films over and over again. She helps him work through his frustration in the filmmaking process. Swanberg's The Zone similarly twists towards self-reflexivity; saying something about collaboration, and social thought.

Richard Brody poetically details his thoughts on Swanberg's process, appropriately addressing a filmmaking process that is social and naked, rather than narcissistic.

Filmmakers who make films about their lives are beginning to think about their lives as they're lived off-screen. As Socrates said, those who imitate should beware "lest, from the imitation, they draw off some of the being." Here the line between imitation and being has been effaced, and the actors—or, rather, the people onscreen - are in a zone of total vulnerability and total complicity. The closed space of the cinema cries out for the door to be opened-and a camera is running outside, too (2012, New Yorker).

\section{Discussion/Implications}

Where does this leave us? What hope is there, truly, for an autonomous, alternative cinema? There has been potential before, as with the work of New Queer Cinema. Yet this once claimed movement, was declared a "moment" by B. Ruby Rich.

Playing a version of himself in his film Silver Bullets (2011), Swanberg addresses his directorial practice to an actress and offers some sort of solution, or consolation.

"I would not pick up a camera for the rest of my life, or never make a movie again if I found something else to make me happy, because movies do not make me happy. Making them does not make me happy. Watching them does not make me happy. Mostly I am just really critical and I hate everything. [It] is no Thing that the movies could get. Me. They get me close to people. That's all that is left. You know? Making movies allows me to get close to people that I find interesting. That's probably why I am still doing it."

Friendship maybe is all we have. But, do not take this as a small accomplishment. Anyone who chooses filmmaking as a career is not choosing the easy way out. Quite the opposite. But then enter the idea that anyone who is choosing filmmaking for a career truly feels that filmmaking is a profound art, worth devoting your time to. This can then cause rift's when you differ from friends in how one sees filmmaking. To quote from Godard, on his deteriating relationship with Truffaut in the 1970s, 
"When you cease to share ideas about movies, when you cease to love the same films, you fight- and you separate. The friendship dies."

The fact that for a period of time, the New Wave collaboratively even existed has been enough for generations of filmmakers afterward to pick up a camera.

New Queer Cinema director Cheryl Dunye created The Owls in 2010. Within the film, there is a talking head interview of the actress. Candidly, she says -"I'm starting to age, these hands are starting to wrinkle I'm getting grey hairs and I'm really feeling lost, further lost from where I began, in my spiritual journey to sisterhood to empower hood to building community. I'm lost." She had taken a step forward towards this empower hood to building community in the building of this very film. The film returns queer cinema back to its population, through collectivity. The Owls, made for $\$ 22,000$ is a collective act created by New Queer Cinema’s Cheryl Dunye, re-thinking how to make films that matter outside the system. The Owls Parliament states,

We created our own system, peopled by lesbians, queers and people of color, film professionals all raising themes about aging as well as inter-generational dialogue; loneliness and community; dreams raised and deferred; butch/trans anxiety; cross-racial and inter-racial desire and strain; and the history of lesbian cinema and self-representation.

In our modern world, the populace misinterprets and ultimately ignores Swanberg's work has been misinterpreted as narcissistic. Yet, going into the Cultural Industries is much more courageous than many other trades. This process is so intimate and grueling that Swanberg who is "interested in the million tiny death that occur in everyday human interactions." These micro budget filmmakers need respect, admiration. It needs people who will help; without compensation and figures who will continue to push them and make them work. At Ryan and Deidre's wedding, there was as much of a focus on the couple's continuing artistic practice as their relationship. Recognizing risk, selfsacrifice, and selflessness is important for spectators.

Seen in Swanberg's ego network is meticulous, selfless, and even volatile support built on mutual appreciation. Swanberg and Gerwig's relationship barely survived the filmmaking of Nights and Weekends; a film about a long distance relationship that mirrored reality as the two drifted away towards different sects in the industry during gaps in the long filmmaking.

Understanding this, and understanding the plight of these post-graduate artists towards uncapitalistic means, can open up more room to maneuver in society and the film industry. In her article "From 3d to Mumblecore" (2011), Brigitta Wagner praises the ingenuity and burgeoning maturity of Joe Swanberg's Art History as "both an homage to collaborative filmmaking in the era of HD and Craigslist (where Swanberg finds his sets) and a testament to the broader implications of image making in a culture saturated with instant representations." Localized collaboration on an independent micro-budget level seems to be a continuing trend. Groups and networks that have popped up to serve a specific purpose that can be engendered through community and collaboration. Recognizing that collaboration drives the local the theatre industry, Split Pillow (of Chicago) has been able to reinvigorate the micro-cinema of their city through well-chosen partnerships. Michigan Creative Film Alliance was created as a union between Michigan State University, University of Michigan and Wayne State for the public to understand the importance of collaboration as a tool to combat the "brain drain" of talented young filmmakers to the east and west coasts (Wunder, 2011). Kodwo Eshun sees that "the return to the artistic practice of the Black Audio Film Collective entails the return of criticality and its discontents. One is confronted with a scale, a sensibility, a temporality, and an ambition that remains singular, even as its influence is discernible throughout postmodern culture" (2004, p.39).

Writing in his blog article "A Call for Collaboration," micro-budget filmmaker Robert Curry writes that a collaborative mode of filmmaking is already becoming popular in Philadelphia.

But a communication between collectives in different regions would better the chances of exhibition and production, and a web of such collectives would without a doubt ensure some form of national exposure. It's time to take the cinema back to the artists in this country. But a communication between collectives in different regions would better the chances of exhibition and production, and a web of such collectives would without a doubt ensure some form of national exposure. It's time to take the cinema back to the artists in this country (2014, para. 4).

There is hope for more autonomous film. Digital technology has something to do with it, so does the drive of individuals. But most importantly, it is the work of a community. Helping others succeed and connect, taking Craigslist casting calls for no money, and helping assist those who need a helping hand. The reason one can't find any good movies browsing on Netflix, is because they aren't out currently helping those willing to make alternative film because to make a film you need more people. "Over the past few decades in the West, we have entered a 
period of hyper individualism, which has its pros and cons. But the power of billions of connected individuals, now flexing more power than markets, governments, and corporations, using new ideas our economic model cannot yet comprehend should be welcomed" (Mason, 2011, p. 240).

When filming Fitzcaraldo, Herzog eventually had the chance to look up at the gigantic ship he had only before in his dreams seen at the top of a mountain. At the end of a tumultuous shoot that took years longer than planned, he ponders; that it is a beautiful metaphor he just doesn't know what the metaphor is. The ship could in fact be relevant his sustained relationship with Klaus Kinski, who through five movies, fights, death threats, the two stayed together longer than one would believe possible until they would eventually split. Herzog recounts in his documentary My Best Friend that he did not wish to direct the brilliant, but notoriously difficult actor's, script. Directing the movie was said to destroy Kinski.

The key about autonomous cinema in our future, is that hopefully when searching for it, you won't be alone. And that, is enough.

\section{References}

Atton, C. (2001). The mundane and its reproduction in alternative media. Journal of Mundane Behavior,2(1), 122-37.

Banks, M., Lovatt, A., O’Connor, J., \&Raffo, C. (2000). Risk and trust in the cultural industries. Geoforum, 31(4), 453-464.

Beier, Y. (2014). The collaborative advantage.Communication World,31(1), 22-25,6.

Belton, J. (2002). Digital cinema: a false revolution.October, 99-114.

Blair, H. (2003). Winning and losing in flexible labour markets: The formation and operation of networks of interdependence in the UK film industry.Sociology,37(4), 677-694.

Borers, E. F. (2010). Working in an artist collective in Portland Oregon: The Artistic Benefits of Cooperation and Place in an Underground World.

Borgatti, S. P., \& Everett, M. G. (2000). Models of core/periphery structures.Social Networks,21(4), 375-395.

Borgatti, S.P., Everett, M.G., \& Freeman, L.C. (2002). Ucinet for Windows: Software for Social Network Analysis. Harvard, MA: Analytic Technologies.

Borgatti, S. P., Everett, M. G., \& Johnson, J. C. (2013). Analyzing Social Networks (1 ed.). Los Angeles i.e. Thousand Oaks, Calif.; London: SAGE Publications Ltd.

Brody, R. (2012, June 18). Go See Tonight: Joe Swanberg's "The Zone". The New Yorker. Retrieved October 15, 2015 , from http://www.newyorker.com/culture/richard-brody/ go-see-tonight-joe-swanbergs-the-zone

Catmull, E. (2008). How Pixar fosters collective creativity. Harvard Business School Publishing.

Cattani, G., \&Ferriani, S. (2008). A core/periphery perspective on individual creative performance: Social networks and cinematic achievements in the Hollywood film industry.Organization Science, 19(6), 824-844.
Cavendish, P. (2013).The Men with the Movie Camera: The Poetics of Visual Style in Soviet Avant-Garde Cinema of the 1920s. Berghahn Books.

Chandler, D. (1995). Technological or media determinism.URL (consulted 21 June 2001): http://www. aber. ac. uk/media/ Documents/tecdet/tecdet. html.

Coe, N. M. (2000). The view from out West: Embeddedness, inter-personal relations and the development of an indigenous film industry in Vancouver.Geoforum,31(4), 391-407.

Colins, C. (2013). 'You're Next': How a Group of Indie Filmmakers Produced one of 2013's Most Terrifying Movies. New York Times.

Contractor, N. S., Wasserman, S., \& Faust, K. (2006). Testing multitheoretical, multilevel hypotheses about organizational networks: An analytic framework and empirical example. Academy of Management Review,31(3), 681-703.

Cooley, C. H. (1909). Social Organization. New York: Charles Scribner's Sons.

Cunningham, S., Silver, J., \& McDonnell, J. (2010). Rates of change: Online distribution as disruptive technology in the film industry.

Daskalaki, M. (2010). Building 'bonds' and 'bridges': Linking tie evolution and network identity in the creative industries. Organization Studies,31(12), 1649-1666.

Daskalaki, M., \& Blair, H. (2002). Knowing' as an activity: Implications for the film industry and semipermanent work groups. InOrganisational Knowledge, Learning and Capabilisecures Athens Conference, Athens.

Deuze, M. (2007). Convergence culture in the creative industries. International Journal of Cultural Studies, 10(2), 243-263. 
Di Vincenzo, F., \&Mascia, D. (2012). Social capital in project-based organizations: Its role, structure, and impact on project performance.International Journal of Project Management,30(1), 5-14.

Dijk, J. A. G. M. van. (2012). The Network Society (3rd ed.). Thousand Oaks, CA: SAGE Publications Ltd.

Dobson, J. (2012). Negotiating the Auteur: Dominique Cabrera, NoémieLvovsky, Laetitia Masson and Marion Vernoux. Manchester; New York: Manchester University Press.

Dougherty, N. (2009). Group developing area's filmmaking capacity.Rochester Business Journal,25(32), 22.

Elder, R. K. (2006). Group fosters grass-roots filmmaking. Retrieved from http://search.proquest.com/ docview/463055727?accountid $=10559$

Eliashberg, J., Elberse, A., \&Leenders, M. A. (2006). The motion picture industry: Critical issues in practice, current research, and new research directions.Marketing Science,25(6), 638-661.

Fair, J. (2008). The 72 Project: using filmmaking to empower networks and foster creative collaboration. MeCCSA Conference Spaces \& Places of Culture 9-11 January 2013

Feld, S., \& Carter, W. C. (1998). Foci of activity as changing contexts for friendship.Placing Friendship in Context, 136-152.

Felton, E., Collis, C., \& Graham, P. (2010). Making connections: Creative industries networks in outer-suburban locations. Australian Geographer,41(1), 57-70.

Fischer, C. S. (1982). To Dwell Among Friends: Personal Networks in Town Andcity. Chicago: The University of Chicago Press.

Fowler, J. H., \& Christakis, N. A. (2008). Dynamic spread of happiness in a large social network: Longitudinal analysis over 20 years in the Framingham Heart Study.Bmj,337, a2338.

Fox, B. (2004). Rethinking the Amateur.Spectator,24(1).

Freeman, L. (2006). The Development of Social Network Analysis. Vancouver: Empirical Press.

Galaskiewicz, J., Bielefeld, W., \& Dowell, M. (2006). Networks and organizational growth: A study of community based nonprofits.Administrative Science Quarterly,51(3), 337-380.

Gall, A. Towards An Imperfect Film Practice. (2010).

Gamson, J. (1996). The organizational shaping of collective identity: The case of lesbian and gay film festivals in New York. InSociological Forum(pp. 231-261). Kluwer Academic Publishers-Plenum Publishers.

Gauntlett, D. (2011). Making is Connecting (1st ed.). Polity.

Gilbey, R. (2013). "Mumblecore: 'It Was Never a Unified Movement. There Was No Manifesto'” The Guardian. Guardian News and Media, 7 Nov. 2013. Web. 5 Dec. 2013. <http://www.theguardian.com/film/2013/nov/07/ mumblecore-andrew-bujalski-computer-chess $>$.
Granovetter, M. (1978). Threshold models of collective behavior. American Journal of Sociology, 1420-1443.

Granovetter, M. S. (1973). The strength of weak ties. The American Journal of Sociology, 78, 1360-80.

Hawe, P., Webster, C., \&Shiell, A. (2004). A glossary of terms for navigating the field of social network analysis.Journal of Epidemiology and Community Health,58(12), 971-975.

Hodge, C. (2009). Film collaboration and creative conflict. Journal of Film and Video,61(1), 18-30.

Hopkins, K. (2011). Group calls for changes to alaska filmmaking subsidy. Retrieved from http://search.proquest.com/ docview/904184402 ?accountid $=10559$

Irwin, J. R. (2004). On digital media as a potential alternative cinema apparatus: A marketplace analysis.Atlantic Journal of Communication,12(1), 4-18.

Jameson, F. (1990). Postmodernism, or, The Cultural Logic of Late Capitalism (Post-Contemporary Interventions). (Reprint edition.). Duke University Press Books.

Jones, C., \& Walsh, K. (1997). Boundaryless careers in the US film industry: Understanding labor market dynamics of network organizations.IndustrielleBeziehungen/The German Journal of Industrial Relations, 58-73.

Kadushin, C. (2004). Too much investment in social capital?. Social Networks,26(1), 75-90.

Katz, N., Lazer, D., Arrow, H., \& Contractor, N. (2004). Network theory and small groups.Small Group Research,35(3), 307-332.

Lazarsfeld, P. F., \& Merton, R. K. (1954). Friendship as a social process: A substantive and methodological analysis.Freedom and Control in Modern Society,18(1), 18-66.

Lee, K. (2014). An independent friendship: Swanberg and Ross. Fandor. KeyFrame Blog.

Lewis, J. (1998).The New American cinema. Duke University Press.

Lim, K. F. (2006). Translational connections, local competitiveness: Mapping the geographies of filmmaking in/ through Hong Kong. GeografiskaAnnaler: Series B, Human Geography, 88, 337-357.

Livingston, J. (2007). Group Seeks to Spark Filmmaking in Idaho. Retrieved from www.lexisnexis.com/hottopics/ lnacademic

Lorenzen, M., \&Täube, F. A. (2008). Breakout from Bollywood? The roles of social networks and regulation in the evolution of Indian film industry. Journal of International Management,14(3), 286-299.

Luther, K., \&Bruckman, A. (2010). Flash collabs: Collaborative innovation networks in online communities of animators. Procedia-Social and Behavioral Sciences,2(4), 6571-6581. 
MacBean, J. R. (1972). Godard and the DzigaVertov Group: Film and Dialectics.Film Quarterly, 30-44.

Mason, M. (2009).The Pirate's Dilemma: How Youth Culture is Reinventing Capitalism. Simon and Schuster.

Maule, R. (2008). Beyond Auteurism: New Directions in Authorial Film Practices in France, Italy and Spain since the 1980s. Bristol, UK; Chicago, USA: Intellect Ltd.

McKether, W.L. (2008). Revealing social networks in qualitative data: An approachfor increasing analytic firepower in qualitative data analysis. Journal of Ethnographic\& Qualitative Research, 2,183-196.

McRobbie, A. (2002). Clubs to companies: Notes on the decline of political culture in speeded up creative worlds.Cultural Studies, 16(4), 516-531.

McRobbie, A. (2004). Everyone is creative: Artists as pioneers of the new economy.Contemporary Culture and Everyday Life, 186-199.

McRobbie, A. (2010). Re-thinking creative economy as radical social enterprise.Sociology-of-Culture blog, 18 .

Merfeld, L. (2010). Higher Ground: Event Filmmaking's Emerging Cult of Collaboration. Retrieved from http://go.galegroup. $\mathrm{com} / \mathrm{ps} / \mathrm{i}$.do?id=GALE\%7CA238834149\&v=2.1\&u=drexel_main\&it $=r \& p=A O N E \& s w=w \& a s i d=115 \mathrm{fc} 7202 \mathrm{cdd} 5 \mathrm{e}-$ ba0252a708e00342a9

Moody, J., \& White, D. (2003). Structural Cohesion and Embeddedness: A Hierarchical Concept of Social Groups. American Sociological Review, 68(1), 1-25.

Nachum, L., \& Keeble, D. (2003). Neo-Marshallian clusters and global networks: The linkages ofmedia firms in Central London. Long Range Planning, 36, 459-480.

Naficy, H. (2001).An Accented Cinema: Exilic and Diasporic Filmmaking. Princeton: Princeton University Press.

Newman, M.Z. (2011). In pursuit of the authentic autonomous alternative.Cinema Journal,48(3), 16-34.

Newman, M. Z. (2011). Indie: An American Film Culture. Columbia University Press.

O’Malley, A. J., \& Marsden, P. V. (2008). The analysis of social networks.Health Services and Outcomes Research methodology, 8(4), 222-269.

Ralon, L. (2009).Beyond categorization: Marshall McLuhan, Technological Determinism, and Social Science Methodology-a Reappraisal(Doctoral dissertation, School of CommunicationSimon Fraser University).

Rafferty, T. (2006). Now playing: Auteur vs. Auteur.New York Times, 22 .

Rogers, E.M. (1962). The Diffusion of Innovations. Glencoe, IL: Free Press.
Sabal, R. (2009). The individual in collaborative media production.Journal of Film and Video,61(1), 6-17.

San Filippo, M. (2011). A cinema of recession: Micro-budgeting, micro-drama, and the "Mumblecore" movement. Cineaction, 85 .

Sarris, A. (2007). Notes on the 'Auteur' Theory in 1962. KwartalnikFilmowy, 59, 6-17.

Sellors, C. P. (2011). Film Authorship: Auteurs and Other Myths. London; New York: Wallflower Press.

Shand, R. (2008). Theorizing amateur cinema: Limitations and possibilities.The Moving Image,8(2), 36-60.

Sickels, R. (2011). American Film in the Digital Age. Retrieved from http://site.ebrary.com/id/10437223

Simonton, D. K. (2004). Group artistic creativity: Creative clusters and cinematic success in feature films.Journal of Applied Social Psychology,34(7), 1494-1520.

Singer, M. (2012). Filmmaker Joe Swanberg and Critic Devin Faraci Clash at Fantastic Fest. Retrieved from http://blogs.indiewire.com/criticwire/ devin-faraci-joe-swanberg-fantastic-fest-debates

Smith, R. (2011). Beyond DIY to Do-It-Together - Mn Artists. Retrieved March 2, 2015, from http://www.mnartists.org/ article/beyond-diy-do-it-together

Sterritt, D. (1998). Staff writer of The Christian, Science Monitor. Celebrating an 'indie' filmmaking team. The Christian Science MonitorRetrieved from http://search. proquest.com/docview/405628002 ?accountid=10559

Stimson, B., \& Sholette, G. (2007).Collectivism after Modernism: The Art of Social Imagination after 1945(1st ed.). Minneapolis, MN: UnivOf Minnesota Press.

Strandvad, S. M. (2012). Organizing for the auteur: A dual case study of debut filmmaking.Journal of Media and Communication Research,28(53), 18-p.

Tryon, C. (2007). New media studies and the new internet cinema.Info: Ann Arbor, MI: Scholarly Publishing Office, University of Michigan Library, 5(1).

Tryon, C. (2013). On-Demand Culture Digital Delivery and the Future of Movies. Retrieved from http://lib.myilibrary. com?id $=486972$

Tzioumakis, Y. (2012). Reclaiming independence: American independent cinema distribution and exhibition practices beyond Indiewood.Mise au point. Cahiers de l'associationfrançaise des enseignantsetchercheursencinéma et audiovisuel, (4).

Verbrugge, L. M. (1977). The structure of adult friendship choices.Social Forces, 56(2), 576-597.

Wellman, B., \& Berkowitz, S.D. (1988). Social Structures: A Network Approach. Cambridge: Cambridge UniversityPress. 
Wry, T., Lounsbury, M., \& Glynn, M. A. (2011). Legitimating nascent collective identities: Coordinating cultural entrepreneurship.Organization Science,22(2), 449-463.

Wunder, F. (2011). Michigan's Major Public Universities Premiere Collaborative Film "Appleville". Retrieved from http://search. proquest.com $/$ docview $/ 856084116$ ?accountid $=10559$

Wyatt, S. (2008). Technological Determinism Is Dead; Long Live Technological Determinism. In E. J. Hackett (Ed.), The Handbook of Science and Technology Studies. MIT Press; Published in cooperation with the Society for the Social Studies of Science.

Yuan, J. (2011, Oct 24). Hollywood on the L Train. Retrieved fromhttp://search.proquest.com/ docview/898535255?accountid $=10559$ 